\title{
Deficits in KCC2 and activation of the HPA axis lead to depression- like behavior following social defeat
}

\author{
Stephanie Miller and Jamie Maguire* \\ *Correspondence: Jamie.Maguire@tufts.edu

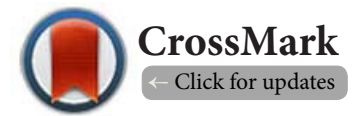 \\ Department of Neuroscience Tufts University School of Medicine, Boston, MA, USA.
}

\begin{abstract}
Background: Chronic social stress triggers the development of major depression in humans and depression-like behavior in animal models. Hyperexcitability of the hypothalamic-pituitary-adrenal (HPA) axis has been implicated in the pathophysiology of depression. The HPA axis is tightly controlled by GABAergic inhibition at the level of corticotrophin-releasing hormone (CRH) neurons in the paraventricular nucleus (PVN) of the hypothalamus. Recently, our lab has demonstrated plasticity in GABAergic control of the HPA axis following stress, involving downregulation of the $\mathrm{K}^{+} / \mathrm{Cl}^{-}$co-transporter 2 (KCC2) which is critical for the inhibitory actions of GABA. The purpose of this study was to determine if chronic social defeat stress activates the HPA axis using similar mechanisms which may contribute to the development of depression-like behavior.

Methods: The activation of the HPA axis following social defeat was quantified by measuring circulating levels of corticosterone (CORT). The role of KCC2 in activation of the HPA axis following social defeat was assessed by measuring KCC2 levels in the PVN by Western blot analysis. The impact of HPA axis activation on depression-like behavior was examined using the forced swim test. The therapeutic potential of blocking the activation of the HPA axis for depression-like behavior was determined by pharmacological blockade of the HPA axis activation, using Antalarmin.

$\underline{\text { Results: }}$ Here, we demonstrate that chronic social defeat stress increased plasma levels of CORT and depression-like behavior in submissive mice. The activation of the HPA axis in submissive mice following chronic social defeat stress was associated with a dephosphorylation and downregulation of KCC2 in the PVN, which has previously been demonstrated to play a key role in mounting the physiological response to stress. Elevations in corticosterone levels and the development of depression-like behavior were restricted to submissive mice and were not observed in dominant animals. Treatment of dominant mice with exogenous corticosterone induced submissive behaviors and depression-like behaviors in these animals. In addition, blocking CRH signaling with Antalarmin prevented the social stress-induced development of depression-like behavior in submissive mice.

Conclusions: Our study suggests that plasticity in the GABAergic regulation of the HPA axis may underlie elevations in corticosterone following chronic social defeat and that blocking the activation of the HPA axis may have therapeutic potential to combat social stress-induced depression.
\end{abstract}

Keywords: Stress, social defeat, KCC2, GABA, depression, corticotropin-releasing hormone (CRH), corticosterone

\section{Introduction}

Major depressive disorder is one of the most prevalent mood disorders, affecting approximately $6.7 \%$ of the population at any one time [1] and up to $20 \%$ of the population at some point in their lives [2]. Depression is associated with numerous longterm, adverse consequences on health, longevity, and quality of life [2-7]. Chronic social and psychological stress trigger the development of depression in both humans $[\mathbf{2 , 8}, \mathbf{9}]$ and animal models [2,9-11]. For example, bullying in both children at school and in adults in the workplace is extremely stressful for the victims and causes many negative consequences, including depression [12-17]. However, the mechanism(s) through which stress leads to depression remains unclear.

Although the pathophysiological causes of depression are undoubtedly varied $[\mathbf{2 , 1 8 - 2 1 ]}$, it is clear that major depression is associated with stress and hyperactivity of the hypothalamicpituitary-adrenal (HPA) axis $[2,22,23]$. Dysregulation of the HPA axis precedes the development of depression and is implicated in mediating the effects of stress on depression-like behavior. Consistent with the role of the $[\mathbf{2 4}, \mathbf{2 5}]$ HPA axis in depression, antidepressant treatment normalizes the activity of the HPA axis in depressed patients (for review see [26]), which precedes the therapeutic effects (for review see [26]).

Social, and other types of, stressors stimulate the release corticotropin-releasing hormone $(\mathrm{CRH})$ from the hypothalamus, which then acts in the pituitary gland to signal the release of adrenocorticotropic hormone (ACTH) to elicit the release of cortisol from the adrenal cortex in humans or corticosterone in rodents (CORT) [27-31]. Chronic stress leads to dysregulation of the HPA axis and increased baseline levels of CORT [28-32], which has been proposed to play a role in the pathophysiological mechanisms underlying depression. However, the mechanism(s) through which the HPA axis becomes dysregulated following chronic stress is unknown but understanding these mechanisms will likely provide insight into the pathophysiology of depression. The HPA axis is tightly regulated by GABAergic inhibition at 
Miller et al. Hormonal Studies 2014,

the level of the $\mathrm{CRH}$ neurons in the paraventricular nucleus (PVN) of the hypothalamus [28,33-35]. The inhibitory actions of GABA on $\mathrm{CRH}$ neurons requires the maintenance of the chloride gradient [36-42], a task primarily accomplished by the potassium chloride cotransporter 2 (KCC2) in the adult brain [36,37,41-43]. Recent studies demonstrated a collapse in the chloride gradient in $\mathrm{CRH}$ neurons following acute restraint stress due to dephosphorylation of KCC2 residue Ser940 and downregulation of KCC2 in the PVN [44], which led to decreased GABAergic control of the HPA axis $[\mathbf{4 4 , 4 5 ]}$. KCC2 residue Ser940 controls the surface expression and function of KCC2 [46]. Thus, dephosphorylation of KCC2 residue Ser940 following acute stress likely has a significant impact on maintaining the chloride gradient in these neurons. Although these studies defined the role of KCC2 in GABAergic control of the HPA axis following acute stress [44], it remains unclear how these regulatory mechanisms controlling the HPA axis are altered following chronic stress and if dysregulation may contribute to the development of depression-like behavior.

Here we utilized the chronic social defeat paradigm to investigate the role of the HPA axis in the development of depression-like behavior. The chronic social defeat stress paradigm mimics bullying behavior in humans and leads to depression-like behavior in defeated animals $[10,12,47]$. We hypothesized that plasticity in the GABAergic regulation of the HPA axis may be the mechanism through which the HPA axis becomes activated following social defeat and may contribute to the development of depression-like behavior. Our data demonstrate that chronic social defeat caused dephosphorylation and downregulation of KCC2 in the PVN, which was associated with activation of the HPA axis and depression-like behavior in submissive mice. We demonstrate that exogenous administration of CORT was sufficient to induce depression-like behavior in previously dominant mice. Furthermore, blocking the activation of the HPA axis with the $\mathrm{CRH}$ antagonist, Antalarmin, prevented the development of depression-like behavior that was associated with chronic social defeat stress. These findings suggest that blocking the physiological response to stress may be a therapeutic target for depression.

\section{Methods}

\section{Animal housing}

Male 10- and 6-week-old C57BL/6 mice were purchased from Jackson Laboratory and housed at the Tufts University School of Medicine, Division of Laboratory Animal Medicine. Mice were housed in a temperature- and humidity-controlled environment with a $12 \mathrm{~h}$ light/dark cycle (lights on at $0700 \mathrm{~h}$ ) with food and water available ad libitum. Mice were housed in our colony for at least 5 days after delivery for acclimation after transport prior to experimentation. Separate groups of animals were used for each experiment unless otherwise noted. Animals were handled according to protocols approved by the Tufts University Institutional Animal Care and Use Committee.

\section{Chronic social defeat stress}

Ten-week-old mice for dominant groups were separated and singly-housed 3-5 days before experimental procedures. Mice that were consistently aggressive when paired with 6-week-old mice were selected as dominants. Naïve mice (10 weeks of age) were then individually introduced into the home cage of a dominant mouse. After a 10 minute interaction, the mice were physically separated and housed in custom cages with a perforated divider (Ancare) so the naïve, now submissive mice, were protected from physical interaction but could still see, smell, and hear the dominant mice. If the animals became injured during the interaction, the test was immediately stopped, the animals separated, and excluded from further experimentation. Thereafter, every day for a total of 14 days, the divider was removed for a 10 minute social defeat interaction (see Figure 1 for paradigm schematic and timeline). Prior to social defeat each day, submissive mice were switched to a new dominant's cage to avoid habituation to the same dominant animal. Social defeat interactions took place between 1300 and $1700 \mathrm{~h}$ daily. Interactions were either observed and scored live or videotaped and scored later for attack latency, number of attacks, and number of tail rattles to determine dominance relationships. Dominant mice were chosen which defeated $100 \%$ of the submissive mice. In contrast, submissive mice were chosen in which they never defeated a dominant mouse ( $0 \%$ defeats). Control animals were singly-housed in the social defeat cages and during the experimental groups' daily social defeat, controls had their divider removed for 10 minutes and then replaced. Dominant and control groups were not significantly different in either their forced swim behavior or plasma CORT levels (Figure 2).

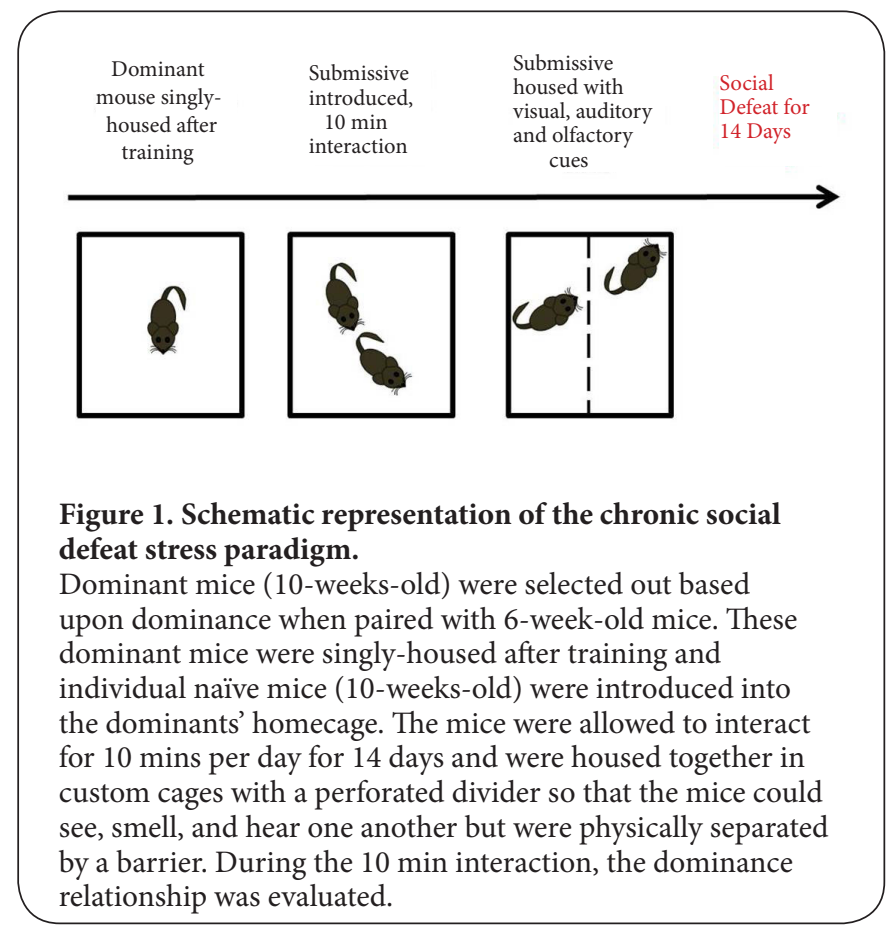




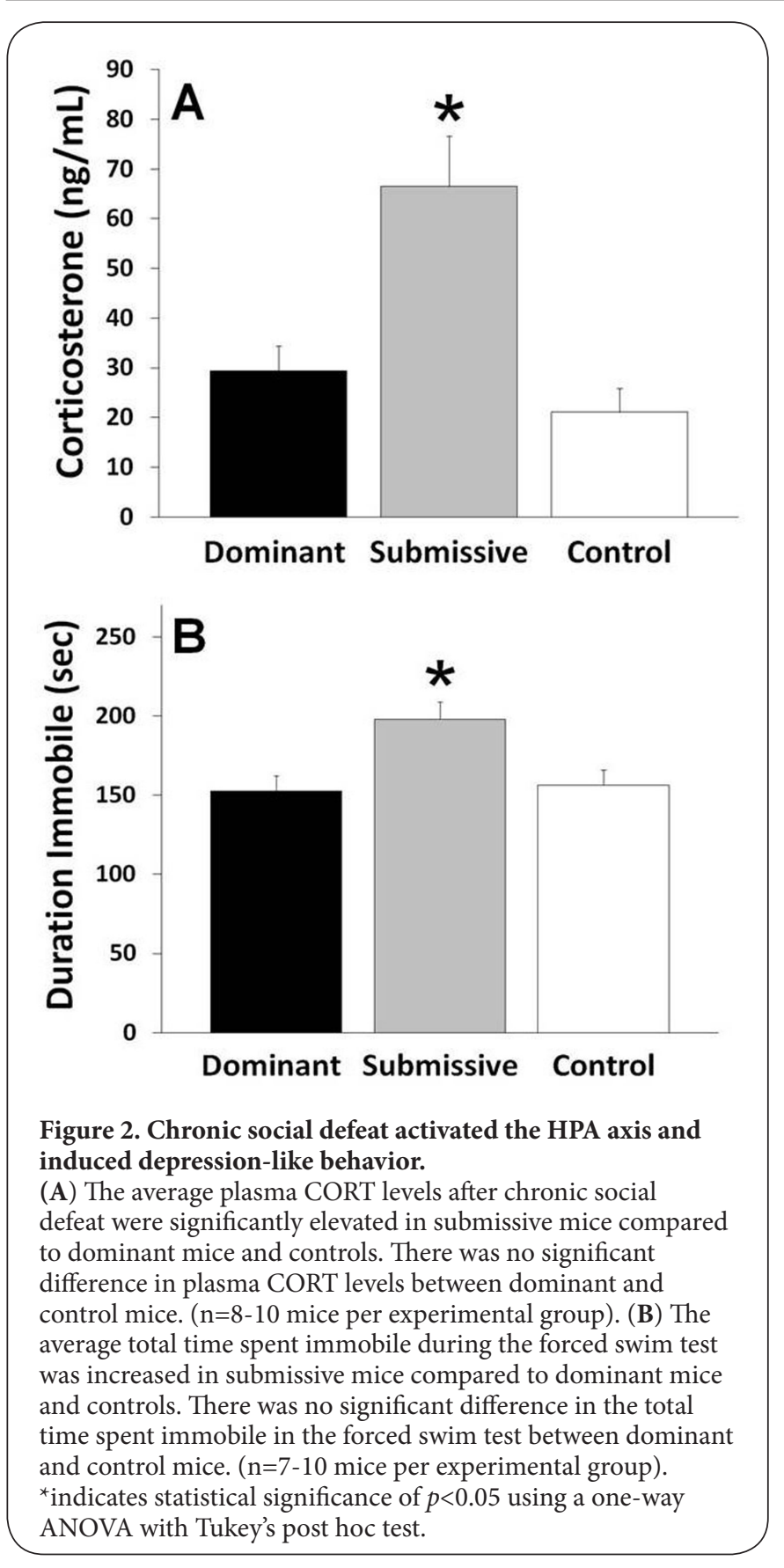

\section{Corticosterone measurements}

Pairs of dominant and submissive mice were briefly anesthetized with isoflurane, decapitated using a guillotine, and trunk blood was collected 30 minutes following subjection to the final social defeat interaction. For the exogenous corticosterone experiments, corticosterone levels were measured 24 hours after the forced swim test. The plasma was isolated from the trunk blood by centrifugation at 14,000 rpm for 5 minutes and then stored at $-20^{\circ} \mathrm{C}$ until use. CORT levels were measured by enzyme immunoassay according to manufacturer's specifications (Enzo Life Sciences). Briefly, plasma samples were assayed in duplicate and absorbance was measured at $415 \mathrm{nM}$ and compared to a standard curve. Samples from different experimental groups were run in parallel.

\section{Forced swim test}

Thirty minutes following the final social defeat interaction, pairs of dominant and submissive mice were placed into separate, adjacent clear plastic containers $22 \mathrm{~cm}$ in diameter, which were filled with approximately $14 \mathrm{~cm}$ of $24^{\circ} \mathrm{C}$ water, for 6 minutes. Containers were cleaned and refilled with fresh water between subjects. After the 6 min forced swim test, animals were removed from the containers, gently patted dry, and then returned to their cages. Sessions were videotaped and then later blindly scored for duration of time spent immobile. A subject was considered to be immobile when it was floating in the water without struggling and using only the small movements necessary to keep its head above water. Testing took place between $1000 \mathrm{~h}$ and $1700 \mathrm{~h}$, with groups being counterbalanced to control for time of day.

\section{Corticosterone pellet implantation}

Mice that were trained as dominants were briefly anesthetized using 2-3\% isoflurane then anesthesia was maintained via a nose cone with $1.5-2 \%$ isoflurane during the implantation surgery. The back of each subject's head and neck was shaved, cleaned, and sterilized using ethanol and betadine. A small, approximately $1 \mathrm{~cm}$ incision was made in the skin on the back of the neck, and a CORT pellet (10 mg/pellet, 21-day release, Innovative Research of America, Sarasota, FL, Catalogue No. G-111,) was implanted (CORT dominant group). An equal number of mice were sham implanted as controls (sham dominant group). Subjects were allowed to recover for 5 days before further experimentation. Following recovery, subjects underwent the chronic social defeat paradigm as dominants. Note that not all naïve animals introduced into CORT dominants' cages were consistently defeated, in contrast to the sham implanted mice, but will be referred to as submissives for consistency and clarity. Thirty minutes after the last social defeat, mice were tested in the forced swim test. Whole blood was collected for analysis of plasma corticosterone levels 24 hours after the forced swim test.

\section{Antalarmin injections}

Submissive mice received daily i.p. injections of either $10 \mathrm{mg} /$ $\mathrm{kg}$ Antalarmin (Sigma, A8727) or vehicle (5\% ethanol and $5 \%$ cremophor, in saline) 30 minutes prior to social defeat throughout the 14 day social defeat paradigm. Antalarminand vehicle-treated submissive mice were tested along with dominant animals in the forced swim test 30 min after their final social defeat on Day 14.

\section{Western blot}

Western blot analysis was conducted as previously described 
Miller et al. Hormonal Studies 2014,

[44]. Thirty minutes after the final social defeat interaction, pairs of dominant and submissive mice and controls were anesthetized with isoflurane, decapitated, brains were rapidly removed, and the PVN was microdissected out. The tissue was placed in homogenization buffer consisting of (in $\mathrm{mM}$ ) 10 $\mathrm{NaPO}_{4}, 100 \mathrm{NaCl}, 10$ sodium pyrophosphate, $25 \mathrm{NaF}, 5 \mathrm{EDTA}$ 5 EGTA, $2 \%$ Triton $X-100,0.5 \%$ deoxycholate, 1 sodium vanadate, $\mathrm{pH} 7.4$, in the presence of protease inhibitors (Complete Mini, Roche) and fresh PMSF, and kept on ice. Samples were then sonicated, incubated on ice for $30 \mathrm{~min}$, centrifuged at 14,000 rpm for $10 \mathrm{~min}$, and the total protein was isolated from the supernatant. Protein concentrations were determined using the DC Protein Assay (Bio-Rad) and $50 \mu \mathrm{g}$ of total protein was loaded onto a $10 \%$ SDS polyacrylamide gel, run via gel electrophoresis at $100 \mathrm{~V}$, and transferred to PVDF membrane (Millipore) overnight at $30 \mathrm{~V}$ at $4^{\circ} \mathrm{C}$. The following day, membranes were blocked in $10 \%$ nonfat milk, probed with a polyclonal antibody specific for KCC2 (1:1000, Millipore), the phosphor-specific antibody for KCC2 residue Ser940 (1:1000, a generous gift from Dr. Stephen J. Moss, Tufts University School of Medicine, Boston, MA), or $\beta$-tubulin (1:10,000, Sigma) and subsequently with either a peroxidase-labeled anti-rabbit IgG (1:2000, GE Healthcare) or anti-mouse IgG (1:2000, GE Healthcare). Immunoreactive proteins were visualized using enhanced chemiluminescence (GE Healthcare) and optical density measurements were made using the NIH ImageJ software.

\section{Statistical analysis}

Plasma corticosterone levels and forced swim immobility durations were compared for statistical significance using one-way ANOVAs with Tukey's post hoc tests to determine group differences which were performed with GraphPad Prism 6 software. For the Western blots, statistical significance was determined using unpaired $t$ tests with Microsoft Excel software. Statistical significance was indicated at $p<0.05$. All data is represented as \pm S.E.M.

\section{Results}

\section{Chronic social defeat stress activated the HPA axis}

To determine if chronic social defeat alters HPA axis responsiveness, we measured circulating CORT 30 min following the last social defeat interaction. Submissive mice showed significantly increased plasma CORT levels $(66.50 \pm 10.15 \mathrm{ng} / \mathrm{ml})$ compared to either dominant mice $(29.41 \pm 4.96 \mathrm{ng} / \mathrm{ml})$ or control mice $(21.07 \pm 4.83 \mathrm{ng} / \mathrm{ml}$ ) (Figure 2A). Interestingly, there was no significant difference in the CORT levels between dominant $(29.41 \pm 4.96 \mathrm{ng} / \mathrm{ml})$ and control mice $(21.07 \pm 4.83 \mathrm{ng} / \mathrm{ml})$ (Figure 2A), suggesting that HPA axis reactivity is only altered in submissive mice ( $\mathrm{n}=8-10$ mice per group; $F(2,25)=3.39$; $p<0.05)$. The mechanism(s) underlying activation of the HPA axis in submissive mice is unclear, but likely directly related to the stress of the social defeat interaction. Previous studies in our lab demonstrated a role for dephosphorylation and downregulation of KCC2 in activation of the HPA axis following acute stress [44]. To determine if this same regulatory mechanism plays a role in dysregulation of the HPA axis following chronic social defeat stress, we examined the total levels of KCC2 and the phosphorylation of KCC2 residue Ser940 in the PVN of dominant and submissive mice using Western blot analysis. We did not observe a difference in the expression of KCC2 or phosphorylation of KCC2 Ser940 between control and dominant mice. Therefore, dominant mice were used for comparison. Submissive mice had significantly decreased expression of total KCC2 in the PVN $(93.59 \pm 2.28$ O.D. units/50 $\mu \mathrm{g}$ total protein) compared to dominant mice $(104.41 \pm 4.25$ O.D. units $/ 50 \mu \mathrm{g}$ total protein) (Figure 3 , Left) ( $n=10$ mice per group; $t(18)=2.24 ; p<0.05)$. In addition, the phosphorylation of KCC2 residue Ser940, which regulates the expression and function of KCC2 [46], was significantly decreased in the PVN of submissive mice ( $38.77 \pm 6.58$ O.D. units $/ 50 \mu \mathrm{g}$ total protein) compared to dominant mice (58.69 \pm 5.47 O.D. units $/ 50 \mu \mathrm{g}$ total protein) (Figure 3, Right), which likely compromises KCC2 function [46] ( $n=10$ mice per group; $t(18)=2.33 ; p<0.05)$. However, we did not observe any difference in the expression of $\beta$-tubulin in the PVN, used as a loading control, between dominant (84.7 \pm 3.1 O.D. units/50 $\mathrm{gg}$ total protein) compared to submissive mice $(80.8 \pm 2.0$ O.D. units $/ 50 \mu \mathrm{g}$ total protein) $(\mathrm{n}=10$ mice per group; $t(18)=-1.06 ; p=0.29)$. These data demonstrate increased activation of the HPA axis only in submissive mice following chronic social defeat stress and may utilize regulatory mechanisms similar to those following acute restraint stress [44].

\section{Chronic social defeat stress induced depression-like behavior}

To determine the impact of social defeat stress on depressionlike behavior, we assessed the total time spent immobile during the forced swim test in dominant, submissive, and control mice following subjection to 14 days of chronic social defeat. Submissive mice spent significantly more time immobile in the forced swim test ( $198.00 \pm 10.77 \mathrm{~s}$ ) compared to dominant mice (152.60 $\pm 9.53 \mathrm{~s})$ and control mice (156.27 $\pm 9.81 \mathrm{~s})$ (Figure 2B), suggesting increased depression-like behavior in submissive mice. Interestingly, dominant mice $(152.60 \pm 9.53 \mathrm{~s})$ did not differ from control mice (156.27 $\pm 9.81 \mathrm{~s})$, similar to the results we observed with circulating CORT levels (Figure 2B) $(\mathrm{n}=7-10$ mice per group; $F(2,28)=3.34 ; p<0.05)$. These data suggest that depression-like behavior is altered in the submissive mice, not the dominant mice. Furthermore, increased depression-like behavior in submissive mice is associated with elevated levels of CORT.

\section{Exogenous CORT was sufficient to induce submissive and depression-like behavior}

As we found significantly elevated levels of plasma CORT in submissive mice following chronic social defeat stress, we wanted to determine whether elevated CORT itself contributes 


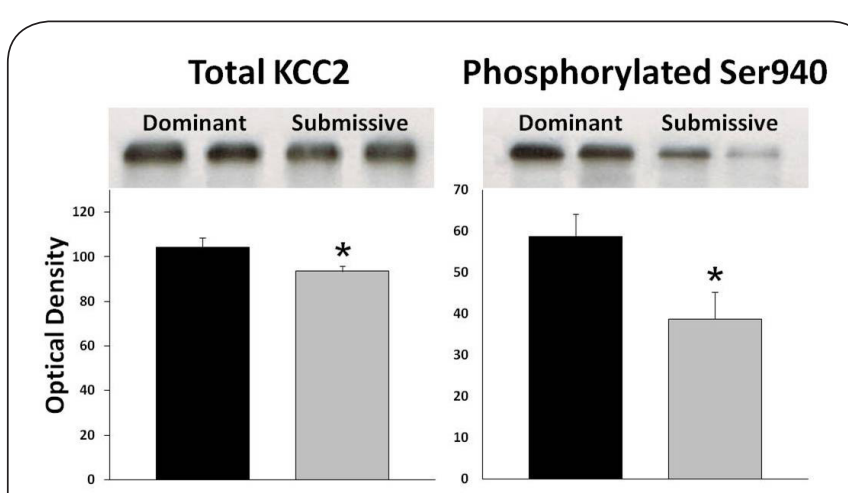

Figure 3. KCC2 was dephosphorylated and downregulated in the PVN following chronic social defeat stress.

Representative Western blots of total KCC2 expression (Left) and phosphorylated Ser940 KCC2 expression (Right) in the PVN of dominant and submissive mice following the chronic social defeat stress paradigm. The average optical density of total KCC2 expression (Left) and KCC2 residue Ser940 phosphorylation (Right) was decreased in submissive mice compared to dominant. ( $\mathrm{n}=10$ mice per experimental group).* indicates statistical significance of $p<0.05$ using a Student's t-test.

to submissive and depression-like behavior. To evaluate the effect of CORT on submissive behavior, we compared the social defeat behavior of dominant mice that received subcutaneous CORT pellets (CORT dominants) to dominant mice receiving a sham surgery (sham dominants) and submissive mice. To ensure that the CORT pellets successfully elevated circulating levels of CORT, we compared basal plasma corticosterone levels of CORT dominants to sham dominants and submissives 24 hours after the forced swim test. CORT levels were significantly elevated in CORT dominants $(57.78 \pm 6.40 \mathrm{ng} / \mathrm{ml})$ compared to sham dominants $(17.57 \pm 1.27 \mathrm{ng} / \mathrm{ml})$ (data not shown) $(\mathrm{n}=10$ mice per group; $p<0.05)$. Importantly, the levels of CORT in CORT dominants $(57.78 \pm 6.40 \mathrm{ng} / \mathrm{ml})$ are similar to what we observed in submissive mice 30 minutes after their final social defeat $(66.50 \pm 10.15 \mathrm{ng} / \mathrm{ml})$. To evaluate the effects of exogenous CORT on behavior, we assessed both the degree of dominance and depression-like behavior. We found that out of the 14 days tested, CORT dominants defeated submissive mice significantly less often ( $4.30 \pm 1.41$ days dominant) than sham dominants ( $10.00 \pm 1.44$ days dominant) (Figure $4 A)(n=10$ mice per group; $p<0.05)$. In fact, CORT dominants $(4.30 \pm 1.41$ days dominant) were not significantly more dominant than submissive mice (0.80 \pm 0.29 days dominant) (Figure 4A). In contrast, sham dominants were significantly more often dominant (10.00 \pm 1.44 days dominant) than submissives $(0.80 \pm 0.29$ days dominant) (Figure $4 \mathrm{~A})$ ( $\mathrm{n}=10$ mice per group; $F(2,27)=3.35 ; p<0.05)$. These data suggest that exogenous CORT is sufficient to abolish dominant behavior. In order to determine whether exogenous CORT affected depression-like behavior in dominant mice, we examined the total time spent immobile in the forced swim test in CORT dominants, sham dominants, and submissive mice. CORT dominants spent significantly more time immobile in the forced swim test (192.80 sec \pm 6.99$)$ compared to sham dominants (159.60 $\pm 8.49 \mathrm{~s}$ ) (Figure 4B), suggesting that CORT treatment induced depression-like behavior in dominant mice. Interestingly, the total time spent immobile was not significantly different between CORT dominants (192.80 $\pm 6.99 \mathrm{~s}$ ) and submissives (201.10 \pm 5.74 s) (Figure 4B). In contrast, sham dominants
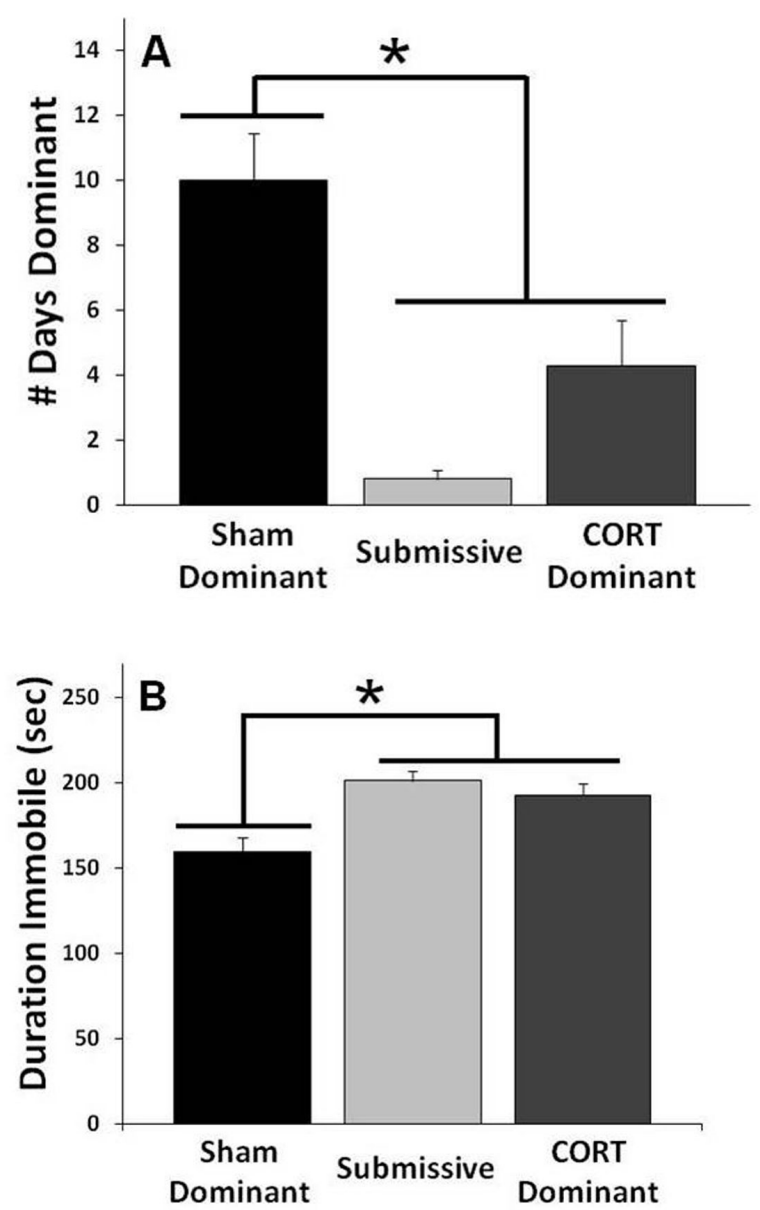

Figure 4. Exogenous CORT decreased dominance and increased depression-like behavior.

(A) The average number of days out of the 14 days of chronic social defeat that each group was dominant over a partner mouse. Exogenous CORT decreased dominant behavior compared to sham treatment. Dominant mice treated with exogenous CORT did not differ significantly from submissive mice in the level of dominance. (B) The average total time spent immobile during the forced swim test in CORT-treated, sham-treated, and submissive mice subjected to the social defeat paradigm. Exogenous CORT treatment increased the total time spent immobile during the forced swim test compared to sham-treatment. In fact, CORT dominants did not significantly differ from submissive mice. $(n=10$ mice per experimental group). ${ }^{\star}$ indicates statistical significance of $p<0.05$ using a one-way ANOVA and Tukey's post hoc test. 
Miller et al. Hormonal Studies 2014,

http://www.hoajonline.com/journals/pdf/2052-8000-2-2.pdf

doi: $10.7243 / 2052-8000-2-2$

spent significantly less time immobile $(159.60 \pm 8.49 \mathrm{~s})$ than submissive mice (201.10 $\pm 5.74 \mathrm{~s})$ (Figure 4B) $(\mathrm{n}=10$ mice per group; $F(2,27)=3.35 ; p<0.05)$. These data suggest that exogenous CORT is sufficient to increase depression-like behavior in dominant mice.

Blocking activation of the HPA axis prevented the development of stress-induced depression-like behavior To test the therapeutic potential of blocking $\mathrm{CRH}$ signaling in treating or preventing social stress-induced depression, we treated submissive mice with i.p. injections of either the $\mathrm{CRH}$ receptor antagonist Antalarmin (Antalarmin submissives) or vehicle (vehicle submissives) 30 minutes prior to social defeat every day. Antalarmin submissives had decreased CORT levels $(39.9 \pm 3.3 \mathrm{ng} / \mathrm{ml}$ ) compared to vehicle submissives $(86.50 \pm 14.8 \mathrm{ng} / \mathrm{ml})$. Depression-like behavior was then assessed in dominants, Antalarmin submissives, and vehicle submissives using the forced swim test. Vehicle-treated submissive mice spent significantly more time immobile $(220.00 \pm 2.95 \mathrm{~s})$ than dominants (186.90 $\pm 3.90 \mathrm{~s})$ (Figure 5), similar to untreated submissive mice (Figure 2B. In contrast, Antalarmin submissives spent significantly less time immobile $(199.13 \pm 8.18 \mathrm{~s})$ than vehicle submissives $(220.00 \pm 2.95 \mathrm{~s})$ (Figure 5) $(\mathrm{n}=14-15$ mice per group; $F(2,55)=10.18 ; p<0.05)$ ), suggesting that Antalarmin treatment decreased depressionlike behavior in submissive mice. In fact, the amount of time Antalarmin submissives spent immobile $(199.13 \pm 8.18 \mathrm{~s})$ was not significantly different from dominants (186.90 $\pm 3.90 \mathrm{~s}$ ). These data indicate that Antalarmin significantly blocked the development of depression-like behavior in submissive mice.

\section{Discussion}

In the present study, we demonstrated that chronic social defeat stress (Figure 1) increased plasma levels of corticosterone and induced depression-like behavior (Figure 2). Activation of the HPA axis following chronic social defeat stress likely utilizes regulatory mechanisms similar to activation of the HPA axis following acute stress, namely dephosphorylation and downregulation of KCC2 (Figure 3). Exogenous CORT was sufficient to induce submissive behavior and to reproduce the depression-like behavior observed following chronic social defeat stress (Figure 4). Further, blocking the HPA axis prevented the social stress-induced development of depression-like behavior (Figure 5), suggesting that targeting the HPA axis may have therapeutic potential.

Our data demonstrate that chronic social defeat stress (Figure 1), an animal model of bullying and social stress in humans $[12,47,48]$, increased corticosterone levels and induced depression-like behavior (Figure 2). These findings are consistent with previous studies using this paradigm $[32,49-54]$, and confirm this as a useful model to examine how chronic social stress leads to depression. It is widely accepted that depression generally results from an interaction between genetic or developmental predispositions and environmental

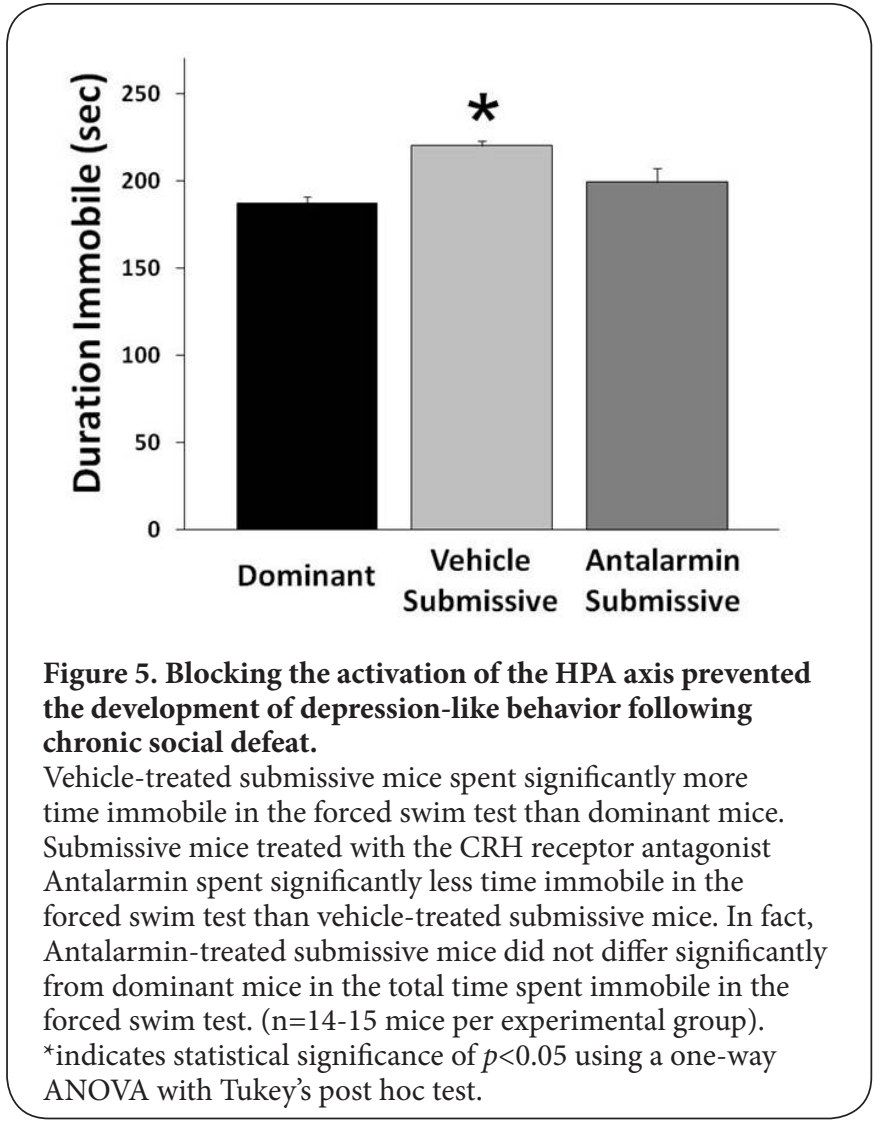

stress $[\mathbf{2}, \mathbf{2 0}, \mathbf{2 2}, \mathbf{2 4 , 3 1 , 5 5 , 5 6 ]}$. Thus, we chose a social stress paradigm for this study due to its translational relevance, as many of the stresses humans encounter are social in nature $[\mathbf{8}, \mathbf{1 7}, \mathbf{4 9}, \mathbf{5 7}, \mathbf{5 8}]$, and other types of stressors, for example physical stressors, are qualitatively different and have different consequences than social stressors [49,58-61]. While we know that chronic social stress leads to depression $[9,11,31,56,62,63]$, we still don't fully understand the mechanisms underlying this process $[2,23,25,59]$. Therefore, to fully combat social stressinduced depression, we need to gain a greater understanding of the role stress itself plays in the development of depression.

Our findings emphasize the important role that CORT plays in causing social stress-induced depression. As mentioned above, we found that submissive mice experienced increased depression-like behavior (Figure 2B) and concurrently increased levels of circulating CORT (Figure 2A), implicating increased CORT in the depression-like behavior. Furthermore, we demonstrate that dominant mice administered exogenous CORT were unable to maintain their status as dominants (Figure 4A) and exhibited increased depression-like behavior (Figure 4B), indicating that CORT itself is sufficient to cause submissive and depression-like behavior. These data are consistent with previous studies demonstrating CORT's involvement in depression-like behavior in animal models $[59,64-69]$ and humans $[70,71]$. The consistent finding across social defeat studies that submissive animals have increased 
Miller et al. Hormonal Studies 2014,

levels of CORT implicate it as a potential causal step leading to subordinate behavior. However, to our knowledge, this is the first study to demonstrate that exogenous CORT can actually interfere with a rodent's ability to be dominant in the social defeat paradigm, and indicates that CORT can directly cause submissiveness. This finding supports the theory that individual differences in regulation of the HPA axis could underlie vulnerability to stress-induced depression [23-25,57,72-74]. Our work confirms previous findings that exogenous CORT leads to depression-like behavior, but expands upon these past results by demonstrating that CORT itself is capable of causing submissive behavior in the social defeat paradigm and is also likely a direct part of the mechanism of how chronic social defeat stress leads to depression-like behavior.

Our data also demonstrate that blocking HPA axis output via antagonizing $\mathrm{CRH}$ receptors with Antalarmin prevented the development of depression-like behavior in defeated mice (Figure 5), indicating this may be a potentially viable treatment for the prevention of social stress-induced depression. Previous studies also implicate the HPA axis in the development of stress-induced depression. In rodents, social defeat stress activates the HPA axis and this activation is mediated by $\mathrm{CRH}[\mathbf{3 1}, \mathbf{5 8 , 7 5}$. Previous work has shown that $\mathrm{CRH}$ receptor antagonism blocks depression-like behavior that is induced by other stressors $[2,22,57,76]$, however, to our knowledge, ours is the first demonstration that $\mathrm{CRH}$ receptor antagonism prevents the development of depression caused by chronic social defeat stress (Figure 5). One study has attempted to treat depression in humans by blocking the HPA axis and found that when R121919, a CRH receptor antagonist, was administered, it reduced symptoms of depression and was well tolerated with little or no side effects and without impairing the normal responsiveness of the HPA axis [77-79]. Unfortunately, a parallel trial of this drug found elevated liver enzymes in patients, which halted further development of R121919 [80]. In addition, more recently, another $\mathrm{CRH}$ receptor antagonist, CP-316,311, also underwent clinical trial, and although it was safe and well tolerated, it failed to decrease depression symptoms [81]. However, other $\mathrm{CRH}$ receptor antagonists are currently undergoing Phase II/III trials and it is possible that these new potentials could be safer and more effective [80]. Interestingly, many antidepressants normalize the HPA axis dysregulation that is associated with depression $[\mathbf{2}, \mathbf{2 2}, \mathbf{2 4}, \mathbf{2 5}, \mathbf{6 6}$, 82-86]. Taken together, these studies conducted in animal models and the clinical trials in depressed patients indicate that, as our results suggest, blocking the HPA axis via the $\mathrm{CRH}$ receptors has the potential to be a powerful therapeutic intervention to treat or prevent depression, but we must continue to search for drugs that are both safe and effective.

Our lab recently discovered a novel mechanism controlling the acute stress-induced activation of the HPA axis, involving dephosphorylation and downregulation of KCC2 [44]. The HPA axis is tightly constrained by the GABAergic inhibition

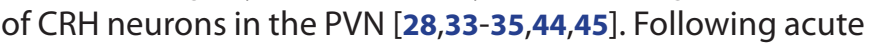

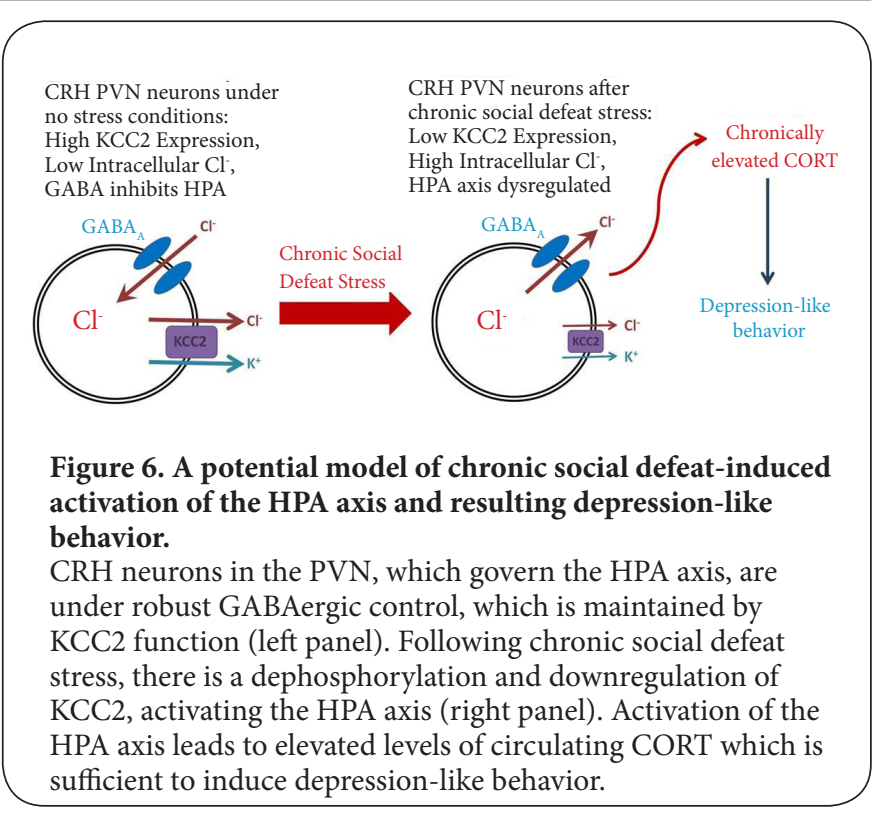

restraint stress, the GABAergic constraint of the HPA axis is lifted enabling the physiological response to stress to be mounted. Decreased GABAergic regulation of $\mathrm{CRH}$ neurons has also been implicated in HPA axis hyperexcitability

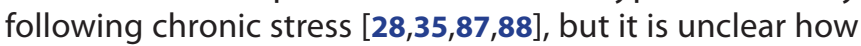
GABAergic inhibition becomes altered. GABAergic inhibition requires the maintenance of the chloride gradient, which is accomplished by KCC2 [36-38,41-43]. Hewitt and colleagues [45] showed that blocking KCC2 activity in the PVN increases HPA axis activity in the form of increased corticosteroid output, indicating that the actions of KCC2 in the PVN are crucial for maintaining inhibitory control over the HPA axis. These alterations in KCC2 may play a critical role in HPA axis dysregulation following chronic social stress. Here we demonstrate dephosphorylation and downregulation of KCC2 following chronic social defeat stress (Figure 3), which may play a role in HPA axis dysfunction. However, additional studies are required to fully investigate the role of KCC2 in HPA axis reactivity following chronic social defeat stress. To date, no studies have examined KCC2 expression after chronic social stress, making ours the first to implicate alterations in KCC2 in HPA axis hyperexcitability in this model. Future studies will determine whether restoration of the chloride gradient and of GABAergic inhibition is a viable therapeutic target for depression.

\section{Conclusions}

We have demonstrated that chronic social defeat caused elevated levels of plasma corticosterone (Figure 2A) and increased depression-like behavior (Figure 2B) in defeated mice. In addition, we have shown that CORT itself caused submissiveness (Figure 4A) and depression-like behavior (Figure 4B) and that blocking the HPA axis with a $\mathrm{CRH}$ antagonist blocked the development of 
Miller et al. Hormonal Studies 2014,

http://www.hoajonline.com/journals/pdf/2052-8000-2-2.pdf

doi: $10.7243 / 2052-8000-2-2$

depression in submissive mice (Figure 5). We have also identified downregulation of the KCC2 transporter in the PVN as a likely mechanism of how chronic stress alters HPA axis function (see Figures 3 and $\mathbf{6}$ ). These data directly implicate stress hormones in the pathophysiological mechanisms underlying the development of depression-like behavior.

\section{Competing interests}

The authors declare that they have no competing interests.

Authors' contributions

\begin{tabular}{|l|c|c|}
\hline Authors' contributions & SM & JM \\
\hline Research concept and design & $\checkmark$ & $\checkmark$ \\
\hline Collection and/or assembly of data & $\checkmark$ & -- \\
\hline Data analysis and interpretation & $\checkmark$ & $\checkmark$ \\
\hline Writing the article & $\checkmark$ & $\checkmark$ \\
\hline Critical revision of the article & -- & $\checkmark$ \\
\hline Final approval of article & $\checkmark$ & $\checkmark$ \\
\hline Statistical analysis & $\checkmark$ & $\checkmark$ \\
\hline
\end{tabular}

Acknowledgement and funding

We would like to thank Dr. Stephen J. Moss for the phosphospecific KCC2 S940 antibody. J.M. was supported by NS073574. The behavioral experiments were conducted in the Tufts Center for Neuroscience Research, P30 NS047243.

Publication history

Editors: Dai Mitsushima, Yamaguchi University, Japan.

Andrew N. Margioris, University of Crete, Greece.

Received: 29-Oct-2013 Revised: 11-Dec-2013

Accepted: 21-Jan-2014 Published: 01-Feb-2014

\section{References}

1. Kessler RC, Chiu WT, Demler O, Merikangas KR and Walters EE. Prevalence, severity, and comorbidity of 12-month DSM-IV disorders in the National Comorbidity Survey Replication. Arch Gen Psychiatry. 2005; 62:617-27. | Article | PubMed Abstract | PubMed Full Text

2. Nestler EJ, Barrot M, DiLeone RJ, Eisch AJ, Gold SJ and Monteggia LM. Neurobiology of depression. Neuron. 2002; 34:13-25. | Article I PubMed

3. Alonso J, Angermeyer MC, Bernert S, Bruffaerts R, Brugha TS, Bryson $\mathrm{H}$, de Girolamo G, Graaf R, Demyttenaere K and Gasquet I et al. Disability and quality of life impact of mental disorders in Europe: results from the European Study of the Epidemiology of Mental Disorders (ESEMeD) project. Acta Psychiatr Scand Suppl. 2004; 38-46. | Article I PubMed

4. Evans DL, Charney DS, Lewis L, Golden RN, Gorman JM, Krishnan KR, Nemeroff CB, Bremner JD, Carney RM and Coyne JC et al. Mood disorders in the medically ill: scientific review and recommendations. Biol Psychiatry. 2005; 58:175-89. | Article | PubMed

5. Gold PW and Chrousos GP. Organization of the stress system and its dysregulation in melancholic and atypical depression: high vs low $\mathrm{CRH} /$ NE states. Mol Psychiatry. 2002; 7:254-75. | Article | PubMed

6. Knol MJ, Twisk JW, Beekman AT, Heine RJ, Snoek FJ and Pouwer F. Depression as a risk factor for the onset of type 2 diabetes mellitus. A meta-analysis. Diabetologia. 2006; 49:837-45. | Article | PubMed

7. Lake CR and Baumer J. Academic psychiatry's responsibility for increasing the recognition of mood disorders and risk for suicide in primary care. Curr Opin Psychiatry. 2010; 23:157-66. | Article | PubMed

8. Brown GW and Prudo R. Psychiatric disorder in a rural and an urban population: 1. Aetiology of depression. Psychol Med. 1981; 11:581-99. | Article | PubMed
9. Buwalda B, Kole MH, Veenema AH, Huininga M, de Boer SF, Korte SM and Koolhaas JM. Long-term effects of social stress on brain and behavior: a focus on hippocampal functioning. Neurosci Biobehav Rev. 2005; 29:8397. | Article | PubMed

10. Rygula R, Abumaria N, Flugge G, Fuchs E, Ruther E and HavemannReinecke $U$. Anhedonia and motivational deficits in rats: impact of chronic social stress. Behav Brain Res. 2005; 162:127-34. | Article | PubMed

11. Schmidt MV, Scharf SH, Sterlemann V, Ganea K, Liebl C, Holsboer F and Muller MB. High susceptibility to chronic social stress is associated with a depression-like phenotype. Psychoneuroendocrinology. 2010; 35:63543. | Article | PubMed

12. Bjorkqvist K. Social defeat as a stressor in humans. Physiol Behav. 2001; 73:435-42. | Article | PubMed

13. Bjorkqvist, Kaj, +ûsterman, Karin, and Hjelt-B+ñck and Monika. Aggression among university employees. Aggressive Behavior. 1994; 20:173-184. | Article

14. Einarsen, Stale, Raknes, Bjorn Inge, and Matthiesen and Stig Berge. Bullying and harassment at work and their relationships to work environment quality: An exploratory study. European Work and Organizational Psychologist. 1994; 4:381-401. | Article

15. Hauge $L J$, Skogstad $A$ and Einarsen $S$. The relative impact of workplace bullying as a social stressor at work. Scand J Psychol. 2010. | Article | PubMed

16. Hawker DS and Boulton MJ. Twenty years' research on peer victimization and psychosocial maladjustment: a meta-analytic review of cross-sectional studies. J Child Psychol Psychiatry. 2000; 41:441-55. | Article I PubMed

17. Huhman KL. Social conflict models: can they inform us about human psychopathology? Horm Behav. 2006; 50:640-6. | Article I PubMed

18. Chopra K, Kumar B and Kuhad A. Pathobiological targets of depression. Expert Opin Ther Targets. 2011; 15:379-400. | Article I PubMed

19. Krishnan $V$ and Nestler EJ. The molecular neurobiology of depression. Nature. 2008; 455:894-902. | Article | PubMed Abstract | PubMed Full $\underline{\text { Text }}$

20. Palazidou E. The neurobiology of depression. Br Med Bull. 2012; 101:127-45. | Article | PubMed

21. Sjoberg RL and Blomstedt P. The psychological neuroscience of depression: implications for understanding effects of deep brain stimulation. Scand J Psychol. 2011; 52:411-9. | Article | PubMed

22. Mitchell AJ. The role of corticotropin releasing factor in depressive illness: a critical review. Neurosci Biobehav Rev. 1998; 22:635-51. | Article | PubMed

23. Pariante CM and Lightman SL. The HPA axis in major depression: classical theories and new developments. Trends Neurosci. 2008; 31:464-8. | Article | PubMed

24. Holsboer F. Stress, hypercortisolism and corticosteroid receptors in depression: implications for therapy. J Affect Disord. 2001; 62:77-91. | Article I PubMed

25. Pariante CM. Risk factors for development of depression and psychosis. Glucocorticoid receptors and pituitary implications for treatment with antidepressant and glucocorticoids. Ann N Y Acad Sci. 2009; 1179:14452. | Article | PubMed Abstract | PubMed Full Text

26. Barden N. Implication of the hypothalamic-pituitary-adrenal axis in the physiopathology of depression. J Psychiatry Neurosci. 2004; 29:185-93. | Pdf | PubMed Abstract | PubMed Full Text

27. Keeney AJ, Hogg S and Marsden CA. Alterations in core body temperature, locomotor activity, and corticosterone following acute and repeated social defeat of male NMRI mice. Physiol Behav. 2001; 74:177-84. | Article | PubMed

28. Cullinan WE, Ziegler DR and Herman JP. Functional role of local GABAergic influences on the HPA axis. Brain Struct Funct. 2008; 213:6372. | Article | PubMed

29. Joels M. Stress, the hippocampus, and epilepsy. Epilepsia. 2009; 50:58697. | Article | PubMed 
Miller et al. Hormonal Studies 2014,

http://www.hoajonline.com/journals/pdf/2052-8000-2-2.pdf

doi: $10.7243 / 2052-8000-2-2$

30. Sterner EY and Kalynchuk LE. Behavioral and neurobiological consequences of prolonged glucocorticoid exposure in rats: relevance to depression. Prog Neuropsychopharmacol Biol Psychiatry. 2010; 34:777-90. | Article | PubMed

31. Scott Karen A, Tamashiro Kellie L. K and Sakai and Randall R. Chapter 23 - Chronic Social Stress: Effects on Neuroendocrine Function. 2012; 521-534.

32. Keeney AJ, Hogg S and Marsden CA. Alterations in core body temperature, locomotor activity, and corticosterone following acute and repeated social defeat of male NMRI mice. Physiol Behav. 2001; 74:177-84. | Article | PubMed

33. Decavel $C$ and Van den Pol AN. GABA: a dominant neurotransmitter in the hypothalamus. J Comp Neurol. 1990; 302:1019-37. | Article | PubMed

34. Herman JP, Mueller NK and Figueiredo H. Role of GABA and glutamate circuitry in hypothalamo-pituitary-adrenocortical stress integration. Ann N Y Acad Sci. 2004; 1018:35-45. | Article | PubMed

35. Joels Marian, Krugers Harmen J, and Martin Verkuyl J. Chapter 4.7 Modulation of glutamatergic and GABAergic neurotransmission by corticosteroid hormones and stress. 2005; 15:525-544. | Article

36. Ben-Ari Y, Khalilov I, Kahle KT and Cherubini E. The GABA excitatory/ inhibitory shift in brain maturation and neurological disorders. Neuroscientist. 2012; 18:467-86. | Article | PubMed

37. Blaesse P, Airaksinen MS, Rivera C and Kaila K. Cation-chloride cotransporters and neuronal function. Neuron. 2009; 61:820-38. | Article | PubMed

38. Conti L, Palma E, Roseti C, Lauro C, Cipriani R, de Groot M, Aronica E and Limatola C. Anomalous levels of $\mathrm{Cl}$ - transporters cause a decrease of GABAergic inhibition in human peritumoral epileptic cortex. Epilepsia. 2011; 52:1635-44. | Article | PubMed

39. Isomura $Y$, Sugimoto $M$, Fujiwara-Tsukamoto $Y$, Yamamoto-Muraki $S$, Yamada J and Fukuda A. Synaptically activated Cl- accumulation responsible for depolarizing GABAergic responses in mature hippocampal neurons. J Neurophysiol. 2003; 90:2752-6. | Article | PubMed

40. Lee HH, Deeb TZ, Walker JA, Davies PA and Moss SJ. NMDA receptor activity downregulates $\mathrm{KCC} 2$ resulting in depolarizing GABAA receptormediated currents. Nat Neurosci. 2011; 14:736-43. | Article | PubMed Abstract | PubMed Full Text

41. Pellegrino C, Gubkina O, Schaefer M, Becq H, Ludwig A, Mukhtarov M, Chudotvorova I, Corby S, Salyha Y, Salozhin S, Bregestovski P and Medina I. Knocking down of the KCC2 in rat hippocampal neurons increases intracellular chloride concentration and compromises neuronal survival. J Physiol. 2011; 589:2475-96. | Article | PubMed Abstract | PubMed Full Text

42. Rivera C, Voipio J, Payne JA, Ruusuvuori E, Lahtinen $\mathrm{H}$, Lamsa K, Pirvola $\mathrm{U}$, Saarma $\mathrm{M}$ and Kaila K. The $\mathrm{K}+/ \mathrm{Cl}$ - co-transporter $\mathrm{KCC} 2$ renders GABA hyperpolarizing during neuronal maturation. Nature. 1999; 397:251-5. I Article I PubMed

43. Payne JA, Rivera C, Voipio J and Kaila K. Cation-chloride co-transporters in neuronal communication, development and trauma. Trends Neurosci. 2003; 26:199-206. | Article | PubMed

44. Sarkar J, Wakefield S, MacKenzie G, Moss SJ and Maguire J. Neurosteroidogenesis is required for the physiological response to stress: role of neurosteroid-sensitive GABAA receptors. J Neurosci. 2011; 31:18198-210. | Article | PubMed Abstract | PubMed Full Text

45. Hewitt SA, Wamsteeker JI, Kurz EU and Bains JS. Altered chloride homeostasis removes synaptic inhibitory constraint of the stress axis. Nat Neurosci. 2009; 12:438-43. | Article | PubMed

46. Lee HH, Walker JA, Williams JR, Goodier RJ, Payne JA and Moss SJ. Direct protein kinase C-dependent phosphorylation regulates the cell surface stability and activity of the potassium chloride cotransporter KCC2. J Biol Chem. 2007; 282:29777-84. | Article | PubMed

47. Yan HC, Cao X, Das M, Zhu XH and Gao TM. Behavioral animal models of depression. Neurosci Bull. 2010; 26:327-37. | Article | PubMed

48. Krishnan V, Han MH, Graham DL, Berton O, Renthal W, Russo SJ,
Laplant Q, Graham A, Lutter M and Lagace DC. Molecular adaptations underlying susceptibility and resistance to social defeat in brain reward regions. Cell. 2007; 131:391-404. | Article | PubMed

49. Blanchard RJ, McKittrick CR and Blanchard DC. Animal models of social stress: effects on behavior and brain neurochemical systems. Physiol Behav. 2001; 73:261-71. | Article | PubMed

50. Croft AP, O'Callaghan MJ, Shaw SG, Connolly G, Jacquot C and Little HJ. Effects of minor laboratory procedures, adrenalectomy, social defeat or acute alcohol on regional brain concentrations of corticosterone. Brain Res. 2008; 1238:12-22. | Article | PubMed

51. Dadomo H, Sanghez V, Di Cristo L, Lori A, Ceresini G, Malinge I, Parmigiani S, Palanza P, Sheardown M and Bartolomucci A. Vulnerability to chronic subordination stress-induced depression-like disorders in adult 129SvEv male mice. Prog Neuropsychopharmacol Biol Psychiatry. 2011; 35:1461-71. | Article | PubMed

52. Hollis F, Wang H, Dietz D, Gunjan A and Kabbaj M. The effects of repeated social defeat on long-term depressive-like behavior and short-term histone modifications in the hippocampus in male SpragueDawley rats. Psychopharmacology (Berl). 2010; 211:69-77. | Article | PubMed

53. Kudryavtseva NN, Bakshtanovskaya IV and Koryakina LA. Social model of depression in mice of C57BL/6J strain. Pharmacol Biochem Behav. 1991; 38:315-20. | Article | PubMed

54. Lutter M, Sakata I, Osborne-Lawrence S, Rovinsky SA, Anderson JG, Jung $\mathrm{S}$, Birnbaum S, Yanagisawa M, Elmquist JK, Nestler EJ and Zigman JM. The orexigenic hormone ghrelin defends against depressive symptoms of chronic stress. Nat Neurosci. 2008; 11:752-3. | Article | PubMed Abstract I PubMed Full Text

55. Lanfumey L, Mongeau R, Cohen-Salmon C and Hamon M. Corticosteroidserotonin interactions in the neurobiological mechanisms of stressrelated disorders. Neurosci Biobehav Rev. 2008; 32:1174-84. | Article | PubMed

56. Nemeroff CB. The neurobiology of depression. Sci Am. 1998; 278:42-9. PubMed

57. Calabrese F, Molteni R and Riva MA. Antistress properties of antidepressant drugs and their clinical implications. Pharmacol Ther. 2011; 132:39-56. | Article | PubMed

58. Tamashiro KL, Nguyen MM and Sakai RR. Social stress: from rodents to primates. Front Neuroendocrinol. 2005; 26:27-40. | Article | PubMed

59. Gregus A, Wintink AJ, Davis AC and Kalynchuk LE. Effect of repeated corticosterone injections and restraint stress on anxiety and depression-like behavior in male rats. Behav Brain Res. 2005; 156:10514. | Article | PubMed

60. Kavushansky A, Ben-Shachar D, Richter-Levin G and Klein E. Physical stress differs from psychosocial stress in the pattern and time-course of behavioral responses, serum corticosterone and expression of plasticity-related genes in the rat. Stress. 2009; 12:412-25. | Article | PubMed

61. Venzala E, Garcia-Garcia AL, Elizalde N and Tordera RM. Social vs. environmental stress models of depression from a behavioural and neurochemical approach. Eur Neuropsychopharmacol. 2013; 23:697708. | Article | PubMed

62. Keeney A, Jessop DS, Harbuz MS, Marsden CA, Hogg S and BlackburnMunro RE. Differential effects of acute and chronic social defeat stress on hypothalamic-pituitary-adrenal axis function and hippocampal serotonin release in mice. J Neuroendocrinol. 2006; 18:330-8. | Article | PubMed

63. McEwen BS. The neurobiology of stress: from serendipity to clinical relevance. Brain Res. 2000; 886:172-189. | Article | PubMed

64. Gourley SL, Kiraly DD, Howell JL, Olausson P and Taylor JR. Acute hippocampal brain-derived neurotrophic factor restores motivational and forced swim performance after corticosterone. Biol Psychiatry. 2008; 64:884-90. | Article | PubMed Abstract | PubMed Full Text

65. Hill MN, Brotto LA, Lee TT and Gorzalka BB. Corticosterone attenuates the antidepressant-like effects elicited by melatonin in the forced swim test in both male and female rats. Prog Neuropsychopharmacol Biol 
Miller et al. Hormonal Studies 2014,

Psychiatry. 2003; 27:905-11. | Article | PubMed

66. Johnson SA, Fournier NM and Kalynchuk LE. Effect of different doses of corticosterone on depression-like behavior and HPA axis responses to a novel stressor. Behav Brain Res. 2006; 168:280-8. | Article | PubMed

67. Marks W, Fournier NM and Kalynchuk LE. Repeated exposure to corticosterone increases depression-like behavior in two different versions of the forced swim test without altering nonspecific locomotor activity or muscle strength. Physiol Behav. 2009; 98:67-72. | Article | PubMed

68. Murray F, Smith DW and Hutson PH. Chronic low dose corticosterone exposure decreased hippocampal cell proliferation, volume and induced anxiety and depression like behaviours in mice. Eur J Pharmacol. 2008; 583:115-27. | Article | PubMed

69. Zhao Y, Xie W, Dai J, Wang Z and Huang Y. The varying effects of shortterm and long-term corticosterone injections on depression-like behavior in mice. Brain Res. 2009; 1261:82-90. | Article | PubMed

70. Bolanos SH, Khan DA, Hanczyc M, Bauer MS, Dhanani N and Brown ES. Assessment of mood states in patients receiving long-term corticosteroid therapy and in controls with patient-rated and clinicianrated scales. Ann Allergy Asthma Immunol. 2004; 92:500-5. | Article | PubMed

71. Brown ES. Effects of glucocorticoids on mood, memory, and the hippocampus. Treatment and preventive therapy. Ann N Y Acad Sci. 2009; 1179:41-55. | Article | PubMed

72. Derijk RH and de Kloet ER. Corticosteroid receptor polymorphisms: determinants of vulnerability and resilience. Eur J Pharmacol. 2008; 583:303-11. | Article | PubMed

73. Haglund ME, Nestadt PS, Cooper NS, Southwick SM and Charney DS. Psychobiological mechanisms of resilience: relevance to prevention and treatment of stress-related psychopathology. Dev Psychopathol. 2007; 19:889-920. | Article | PubMed

74. Wood SK, Walker HE, Valentino RJ and Bhatnagar S. Individual differences in reactivity to social stress predict susceptibility and resilience to a depressive phenotype: role of corticotropin-releasing factor. Endocrinology. 2010; 151:1795-805. | Article | PubMed Abstract I PubMed Full Text

75. Pich EM, Heinrichs SC, Rivier C, Miczek KA, Fisher DA and Koob GF. Blockade of pituitary-adrenal axis activation induced by peripheral immunoneutralization of corticotropin-releasing factor does not affect the behavioral response to social defeat stress in rats. Psychoneuroendocrinology. 1993; 18:495-507. | Article | PubMed

76. Thomson $F$ and Craighead M. Innovative approaches for the treatment of depression: targeting the HPA axis. Neurochem Res. 2008; 33:691707. | Article | PubMed

77. Kunzel HE, Zobel AW, Nickel T, Ackl N, Uhr M, Sonntag A, Ising M and Holsboer F. Treatment of depression with the CRH-1-receptor antagonist R121919: endocrine changes and side effects. J Psychiatr Res. 2003; 37:525-33. | Article | PubMed

78. Kunzel HE, Ising M, Zobel AW, Nickel T, Ackl N, Sonntag A, Holsboer F and Uhr M. Treatment with a CRH-1-receptor antagonist (R121919) does not affect weight or plasma leptin concentration in patients with major depression. J Psychiatr Res. 2005; 39:173-7. | Article | PubMed

79. Zobel AW, Nickel T, Kunzel HE, AckI N, Sonntag A, Ising M and Holsboer F. Effects of the high-affinity corticotropin-releasing hormone receptor 1 antagonist R121919 in major depression: the first 20 patients treated. J Psychiatr Res. 2000; 34:171-81. | Article | PubMed

80. Zorrilla EP and Koob GF. Progress in corticotropin-releasing factor-1 antagonist development. Drug Discov Today. 2010; 15:371-83. | Article | PubMed Abstract | PubMed Full Text

81. Binneman B, Feltner D, Kolluri S, Shi Y, Qiu R and Stiger T. A 6-week randomized, placebo-controlled trial of CP-316,311 (a selective CRH1 antagonist) in the treatment of major depression. Am J Psychiatry. 2008; 165:617-20. | Article | PubMed

82. Carvalho LA and Pariante CM. In vitro modulation of the glucocorticoid receptor by antidepressants. Stress. 2008; 11:411-24. | Article | PubMed

83. Casarotto PC and Andreatini R. Repeated paroxetine treatment reverses anhedonia induced in rats by chronic mild stress or dexamethasone. Eur Neuropsychopharmacol. 2007; 17:735-42. | Article | PubMed

84. Holsboer F and Ising M. Central CRH system in depression and anxiety-evidence from clinical studies with CRH1 receptor antagonists. Eur J Pharmacol. 2008; 583:350-7. | Article | PubMed

85. Kitayama I, Janson AM, Cintra A, Fuxe K, Agnati LF, Ogren SO, Harfstrand $A$, Eneroth $P$ and Gustafsson JA. Effects of chronic imipramine treatment on glucocorticoid receptor immunoreactivity in various regions of the rat brain. Evidence for selective increases of glucocorticoid receptor immunoreactivity in the locus coeruleus and in 5-hydroxytryptamine nerve cell groups of the rostral ventromedial medulla. J Neural Transm. 1988; 73:191-203. | PubMed

86. van Praag H. M. Can stress cause depression? Prog. Neuropsychopharmacol.Biol.Psychiatry. 2004; 28:891-907.

87. Medina JH, Novas ML, Wolfman CN, Levi de Stein M and De Robertis E. Benzodiazepine receptors in rat cerebral cortex and hippocampus undergo rapid and reversible changes after acute stress. Neuroscience. 1983; 9:331-5. | Article | PubMed

88. Montpied P, Weizman A, Weizman R, Kook KA, Morrow AL and Paul SM. Repeated swim-stress reduces GABAA receptor alpha subunit mRNAs in the mouse hippocampus. Brain Res Mol Brain Res. 1993; 18:267-72. I Article | PubMed

\section{Citation:}

Miller S and Maguire J. Deficits in KCC2 and activation of the HPA axis lead to depressionlike behavior following social defeat. Horm Stud. 2014; 2:2. http://dx.doi.org/10.7243/2052-8000-2-2 